\title{
Pterygopalatine Fossa: Microsurgical Anatomy and its Relevance for Skull Base Surgery
}

\section{Fossa Pterigopalatina: Anatomia microcirúrgica e sua relevância para a cirurgia da base do crânio}

\author{
Gustavo Rassier Isolan ${ }^{1,2}$ Julio Mocellin Bernardi ${ }^{2}$ João Paulo Mota Telles ${ }^{30}$ \\ Nícollas Nunes Rabelo ${ }^{30}$ Eberval Gadelha Figueiredo ${ }^{30}$
}

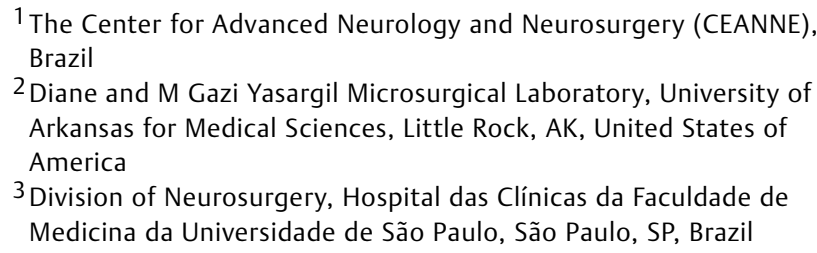

Address for correspondence Eberval Gadelha Figueiredo, MD, PhD, Division of Neurosurgery, Hospital das Clínicas da Faculdade de Medicina da Universidade de São Paulo, Av. Dr. Eneas de Aguiar, 255, São Paulo, SP, 05403-010, Brazil (e-mail: ebgadelha@yahoo.com).

Arq Bras Neurocir 2021;40(1):51-58.

\begin{abstract}
Keywords

- microsurgery

- neuroanatomy

- pterygopalatine fossa

- skull base

Introduction The purpose of this study was to define the anatomical relationships of the pterygopalatine fossa (PPF) and its operative implications in skull base surgical approaches.

Methods Ten cadaveric heads were dissected at the Dianne and M Gazi Yasargil Educational Center MicrosurgicaLaboratory, in Little Rock, AK, USA. The PPF was exposed through an extended dissection with mandible and pterygoid plate removal. Results The PPF has the shape of an inverted cone. Its boundaries are the pterygomaxillary fissure; the maxilla, anteriorly; the medial plate of the pterygoid process, and greater wing of the sphenoid process, posteriorly; the palatine bone, medially; and the body of the sphenoid process, superiorly. Its contents are the maxillary division of the trigeminal nerve and its branches; the pterygopalatine ganglion; the pterygopalatine portion of the maxillary artery (MA) and its branches; and the venous network. Differential diagnosis of PPF masses includes perineural tumoral extension along the maxillary nerve, schwannomas, neurofibromas, angiofibromas, hemangiomas, and ectopic salivary gland tissue. Transmaxillary and transpalatal approaches require extensive resection of bony structures and are narrow in the deeper part of the approach, impairing the surgical vision and maneuverability. Endoscopic surgery solves this problem, bringing the light source to the center of the surgical field, allowing proper visualization of the surgical field, extreme close-ups, and different view angles.
\end{abstract}

received

July 27,2020

accepted

August 5, 2020

published online

October 16, 2020
DOI https://doi.org/ 10.1055/s-0040-1718430. ISSN 0103-5355.

\footnotetext{
(c) 2020. Sociedade Brasileira de Neurocirurgia. All rights reserved. This is an open access article published by Thieme under the terms of the Creative Commons Attribution-NonDerivative-NonCommercial-License, permitting copying and reproduction so long as the original work is given appropriate credit. Contents may not be used for commercial purposes, or adapted, remixed, transformed or built upon. (https://creativecommons.org/ licenses/by-nc-nd/4.0/) Thieme Revinter Publicações Ltda., Rua do Matoso 170, Rio de Janeiro, RJ, CEP 20270-135, Brazil
} 


\section{Resumo}

\author{
Palavras-chave \\ - neuroanatomia \\ - fossa \\ pterigopalatina \\ - base de crânio \\ - microcirurgia
}

Conclusion We provide detailed information on the fossa's boundaries, intercommunications with adjacent structures, anatomy of the maxillary artery, and its variations. It is discussed in the context of clinical affections and surgical approaches of this specific region, including pterygomaxillary disjunction and skull base tumors. Introdução $O$ presente estudo objetiva definir as relações anatômicas da fossa pterigopalatina (FPP) e suas implicações na cirurgia de base de crânio.

Métodos Dez cadáveres foram dissecados no centro educacional Dianne and M Gazi Yasargil, em Little Rock, AK, EUA. A FPP foi exposta via uma dissecção estendida com remoção da mandíbula e placa pterigoidea.

Resultados A FPP tem o formato de um cone invertido. Seus limites são a fissure pterigomaxilar; a maxila, anteriormente; a placa medial do processo pterigoide e a asa maior do processo esfenoide, posteriormente; o osso palatino, medialmente; e o corpo do processo esfenoide, superiormente. Os conteúdos são a divisão maxilar do nervo trigêmeo e seus ramos; o gânglio pterigopalatino; a porção pterigopalatina da artéria e seus ramos; e o plexo venoso. O diagnóstico diferencial de massas da FPP inclui extensão perineural de tumores sobre o nervo maxilar, schwannomas, neurofibromas, angiofibromas, hemangiomas e tecido salivar ectópico. Abordagens transmaxilares e transpalatais requerem ressecção extensa de estruturas ósseas e são estreitas em sua porção mais profunda, dificultando a visão cirúrgica. Cirurgia endoscópica é uma solução para tal, iluminando e possibilitando visualização adequada do centro do campo cirúrgico, aproximação extrema e diferentes ângulos.

Conclusão Descreve-se detalhadamente os limites, intercomunicações e estruturas adjacentes à FPP, anatomia da artéria maxilar e suas variações, com contextualização clínica e cirúrgica.

\section{Introduction}

The pterygopalatine fossa (PPF) is a small area that lies between the maxilla and the middle cranial fossa. It contains multiple delicate vascular and nervous structures and is of great interest to neurosurgeons, otolaryngologists, and maxillofacial surgeons.

Tumors of the FPP are rare; however, their management poses numerous surgical challenges. Transmaxillary approaches are often associated with high morbidity, poor cosmetical results, and possibly bone development disorders. Endoscopic approaches have cosmetic and postoperative advantages, although limited in terms of hemostatic control. ${ }^{1-3}$

Anatomic knowledge of this particular region is paramount because the space is narrow, the structures are packed tightly, and accidental lesions could result in high morbidity. The purpose of the present study was to analyze the microsurgical anatomy of this area to define the anatomical relationships of the PPF with the respective surgical implications for skull base approaches.

\section{Material and Methods}

The dissections were performed by the main author on 10 cadaveric heads at the Dianne and MGazi Yasargil Educational Center Microsurgical Laboratory, in Little Rock, AK, USA. The heads were fixed in formalin. Arteries and veins were colored with latex to enhance their visibility. An anatomical dissection was done via a wide preauricular incision, ranging from the superior temporal line to the neck, on the anterior border of the sternocleidomastoid muscle at the level of the cricoid cartilage. The flap was displaced anteriorly.

The branches of the facial nerve and the parotid duct were dissected. The parotid fascia and parotid gland were removed, preserving the facial nerve. The masseter muscle was cleaned and resected. The superficial temporal fascia and the fat pad were removed along the zygomatic arch, which was then removed. The superficial temporal artery (STA) and the auriculotemporal nerve were identified over the deep temporal fascia. The coronoid process of the mandible was cut and reflected upward together with the temporal muscle tendon, while the insertion of the deep layer of the masseter muscle was resected. The mandible was cut at the level of the neck and the level of the angle. This part of the mandible was removed, and the structures of the infratemporal fossa (ITF) were identified. The IFT fossa muscles were resected, and the lateral pterygoid plate was removed to expose the PPF.

\section{Results}

Boundaries and Contents of the Pterygopalatine Fossa The PPF has the shape of an inverted cone, having as apex the greater palatine canal. Its lateral boundary is the pterygomaxillary fissure (PMF), which communicates the PPF with the infratemporal fossa. The other boundaries of the PPF are the following: the maxilla, anteriorly; the medial plate of the 
pterygoid process and greater wing of the sphenoid process, posteriorly; the palatine bone, medially; and the body of the sphenoid process, superiorly. The maxillary artery (MA), arising medially to the neck of the mandible, and bending in an anterior, medial and slightly superior direction, enters the PPF through the PMF, giving several branches before entering the sphenopalatine foramen as the sphenopalatine artery. The MA can be divided into three parts: the mandibular, pterygoid, and pterygopalatine portions.

The contents of the PPF are the following: (1) maxillary division of the trigeminal nerve and its branches; (2) pterygopalatine ganglion; (3) pterygopalatine portion of MA and its branches; (4) venous network surrounding the MA. The maxillary nerve innervates the lateral aspect of the cheek, the temple, and the maxillary teeth. Its branches are the zygomatic nerve, one or two posterior superior alveolar nerves, infraorbital nerve, and roots to the sphenopalatine ganglion. The maxillary artery is a significant source of blood supply to the deep structures of the face, and also gives rise to the middle meningeal artery. The pterygopalatine ganglion gives rise to postganglionic fibers to the lacrimal gland and

Table 1 Communications of the pterygopalatine fossa to adjacent structures

\begin{tabular}{|l|l|}
\hline Structure & Communication provided by \\
\hline Infratemporal fossa & Pterygomaxillary fissure \\
\hline Orbit & Inferior orbital fissure \\
\hline Nasal cavity & Sphenopalatine foramen \\
\hline Middle cranial fossa & Foramen rotundum \\
\hline Palate & $\begin{array}{l}\text { Greater and lesser palatine } \\
\text { canals and foramina }\end{array}$ \\
\hline Foramen lacerum & Pterygoid canal \\
\hline Vault of pharynx & Pharyngeal canal \\
\hline
\end{tabular}

Table 2 Contents of the structures that communicate with the pterygopalatine fossa

\begin{tabular}{|l|l|}
\hline $\begin{array}{l}\text { Communication } \\
\text { provided by }\end{array}$ & Contents \\
\hline $\begin{array}{l}\text { Foramen } \\
\text { rotundum }\end{array}$ & Maxillary division of fifth cranial nerve \\
\hline $\begin{array}{l}\text { Sphenopalatine } \\
\text { foramen }\end{array}$ & $\begin{array}{l}\text { Sphenopalatine artery and vein } \\
\text { Nasal branches of maxillary nerve }\end{array}$ \\
\hline $\begin{array}{l}\text { Greater and lesser } \\
\text { palatine canals }\end{array}$ & $\begin{array}{l}\text { Greater and lesser nerves, arteries, } \\
\text { and veins } \\
\text { Descending palatine artery }\end{array}$ \\
\hline Pterygoid canal & Vidian nerves, arteries, and veins \\
\hline $\begin{array}{l}\text { Inferior orbital } \\
\text { fissure }\end{array}$ & $\begin{array}{l}\text { Zygomatic branch of maxillary nerve } \\
\text { Infraorbital nerves, arteries, } \\
\text { and veins }\end{array}$ \\
\hline $\begin{array}{l}\text { Pterygomaxillary } \\
\text { fissure }\end{array}$ & $\begin{array}{l}\text { Maxillary artery } \\
\text { Posterior superior alveolar nerve, } \\
\text { artery, and vein }\end{array}$ \\
\hline Pharyngeal canal & \begin{tabular}{l} 
Pharyngeal nerve, artery, and vein \\
\hline
\end{tabular} \\
\hline
\end{tabular}

glands in the nasal and nasopharyngeal mucosa. It is the largest parasympathetic ganglion in the body.

The PPF is a neurovascular hub in the middle face. It communicates with the foramen lacerum, infratemporal fossa, middle cranial fossa, nasal cavity, orbit, and pharynx via foramina and fissures. A summary of the communications is shown in - Table 1. The vascular and nervous structures arising from the PPF are described in - Table 2 . To reach the PPF, the ramus and condyle of the mandible were removed. The contents of the infratemporal fossa were removed using a lateral infratemporal approach.

\section{The Maxillary Artery (MA)}

The MA (-Fig. 1, structure number 5) was found deep into the mandibular ramus. It passed horizontally and gave rise to the buccal artery, which supplied the buccinator muscle. Then, it turned medially and crossed the PMF to arrive in the PPF, thus becoming the pterygopalatine portion of the MA.

Branches arising from this portion of the MA were located at approximately one-third of the height of the maxillary sinus' posterolateral wall. The artery entered the PMF in an anterior, medial, and superior direction, as previously described. While in the PMF, the MA originated two branches, namely, the infraorbital artery (IOA) and the posterosuperior alveolar artery (PSAA). Both arteries were located in the posterior wall of the maxilla. The PSAA entered into the posterosuperior alveolar foramen, while the IOA entered the infraorbital fissure.

After giving off these branches, the MA continued to the PPF. It then split into three arteries: the descending palatine artery (DPA), which supplied the palate; the artery of the pterygoid canal (or Vidian artery, VA); and the sphenopalatine artery (SPA). The PSAA and IOA branched from the MA

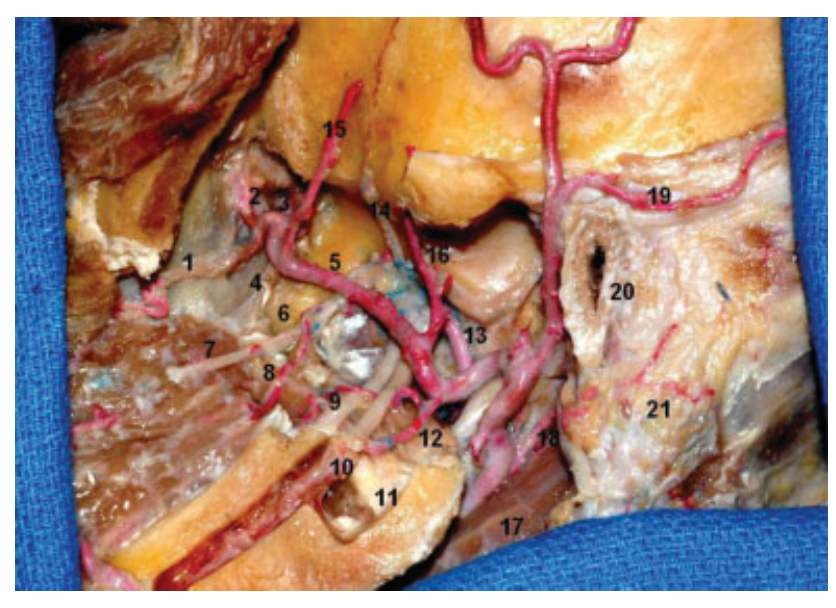

Fig. 1 Lateral view of the infratemporal fossa (ITF). The pterygopalatine fossa is medial to the lateral pterygoid plate. The lateral pterygoid process and the condylar process were removed. 1, posterior superior alveolar artery; 2 , infraorbital artery; 3 , sphenopalatine artery; 4 , descending palatine artery (not injected); 5 , maxillary artery; 6 , lateral pterygoid plate; 7 , buccal nerve; 8 , buccal artery; 9 , lingual nerve; 10 , inferior alveolar nerve; 11 , medial pterygoid muscle; 12 , inferior alveolar artery; 13 , middle meningeal artery; 14 , deep temporal nerve; 15 , anterior deep temporal artery; 16, posterior deep temporal artery; 17, digastric muscle (posterior belly); 18 , posterior auricular artery; 19 , posterior auricular artery; 20 , external acoustic meatus; 21, mastoid. 
with two different patterns. In the first one, a short common trunk arose from the MA, subsequently bifurcating to form both arteries. In the second pattern, the PSAA and IOA branched separately. According to Choi and Park, ${ }^{4}$ both patterns occur with almost equal frequency.

\section{Communications of the Pterygopalatine Fossa}

The bony structures and communications of the PPF are illustrated in -Fig. 2. Regarding the communications of the PPF, an interesting finding was the proximity of the foramen rotundum and pterygoid canal to the sphenoid

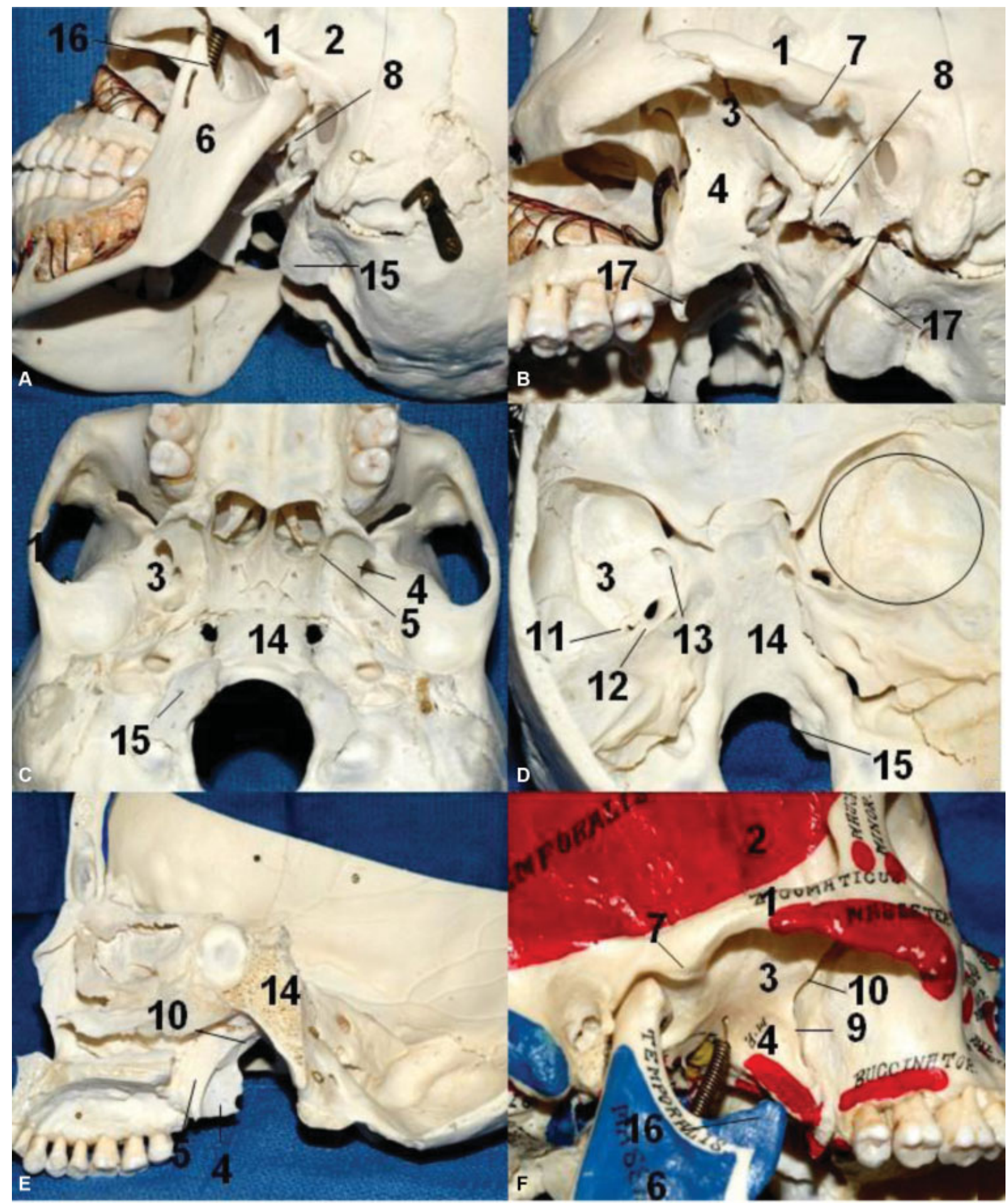

Fig. 2 Limits of the infratemporal fossa, pterygopalatine fossa and bone relationships. (A). Oblique lateral view of the ITF. (B) Same oblique lateral view after removal of the mandible. (C) Inferior aspect of the cranium. (D) Interior view of the cranial base. The circle on the right middle fossa represents approximately the correspondence of the ITF in the middle fossa. (E) Lateral view of the ITF after sagittal paramedian section. (F) Note that the depression of the mandible (open mouth) gives more access to the ITF laterally. 1, zygomatic process of the temporal bone; 2 , temporal fossa; 3 , greater wing of the sphenoid; 4 , lateral pterygoid plate; 5 , medial pterygoid plate; 7 , articular tubercle of the temporal bone; 8 , spine of the sphenoid bone; 9 , pterygomaxillary fissure; 10 , pterygopalatine fossa; 11 , foramen spinosum; 12 , foramen ovale; 13 , foramen rotundum; 14 , clivus; 15 , occipital condyle; 16 , coronoid process; 17 , styloid process. 


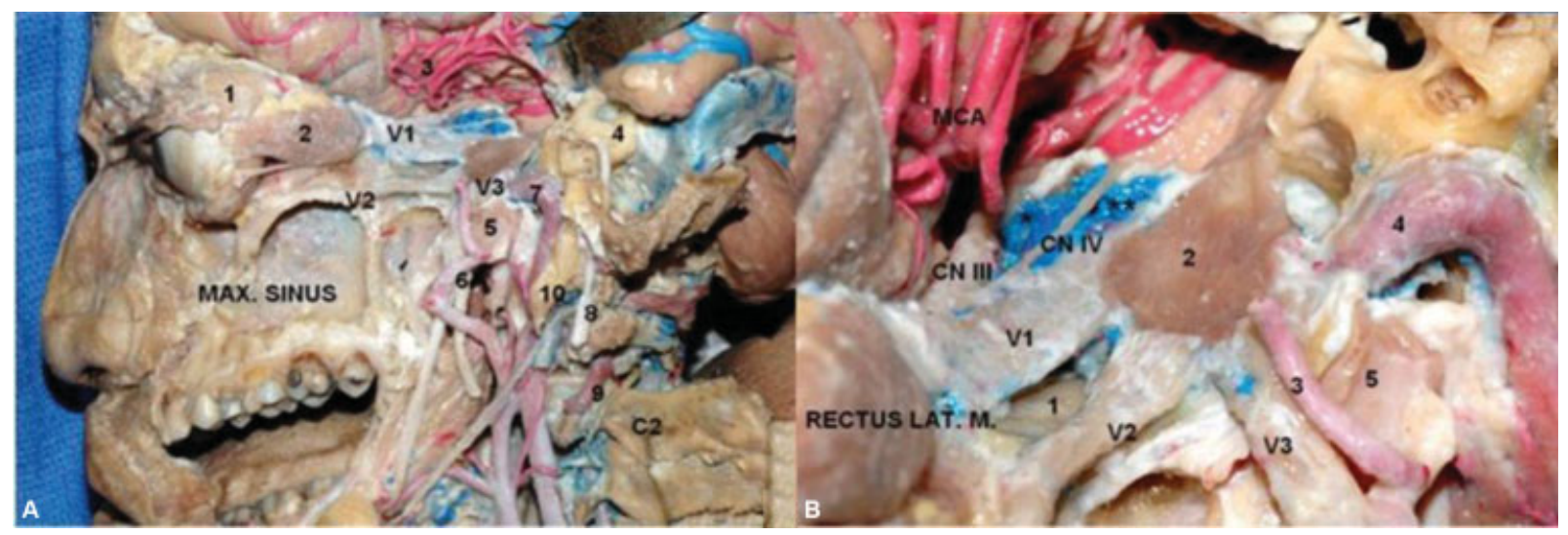

Fig. 3 Lateral view. (A). Were removed the lateral and anterior walls of the maxillary sinus, the walls of the orbit, and the orbital fat. The temporal lobe is displaced posteriorly to expose the cavernous sinus. The dura of the middle fossa was peeled away, and the bone of the middle fossa floor was drilled out to show the anatomical relationship between the temporal and infratemporal fossa structures. Mastoidectomy was performed, preserving the mastoid tip. 1. lacrimal gland; 2 . rectus lateralis muscle; 3 . middle cerebral artery; 4 . otic capsule (semicircular canals); 5. Eustachian tube; 6. middle meningeal artery; 7. internal carotid artery (intrapetrous portion); 8. facial nerve; 9. vertebral artery; 10. styloid process. Max. Maxillary. (B). Middle fossa floor and cavernous sinus. ;1. sphenoidal sinus; 2. Gasserian ganglion; 3. middle meningeal artery; 4 . internal carotid artery (intrapetrous portion); 5 . eustachian tube.

sinus. The pterygoid canal can be completely intrasinusal in 7.5 to $13 \%$ of the cases and may even be in open communication with the sphenoid sinus when the root of the canal is absent. The anterior portion of the pterygoid canal may also be associated with the ethmoid sinus in up to $7 \%$ of cases if the latter is grossly enlarged. Knowledge of those anatomical variations may be useful in the planning of endoscopic surgery and could also explain neural and vascular involvement in inflammatory and neoplastic diseases of the sphenoid and ethmoid sinuses, which occur in some case reports. ${ }^{5-10}$

In the present study, the branching pattern of the MA's pterygopalatine portion was similar to that in other articles. ${ }^{11-14}$ From the PMF to the PPF, the MA branched into five arteries. The first ones to branch were the PSAA and the IOA, followed by the DPA, VA, and SPA, which arose in the PPF region. (-Fig. 3)

The present data indicate that pterygomaxillary disjunction can be safely performed without lacerating the MA or damaging the neural contents of the PPF. This can be accomplished by placing the osteotome inferiorly on the pterygo- maxillary junction (PMJ) and directing it anteriorly and medially. Special care should be taken in not directing the osteotome superiorly. Besides, because the location of the DPA was reported to be an average $24.8 \mathrm{~mm}$ apart from the PMJ [28], the osteotome should be directed inferiorly from the zygomaticomaxillary crest as it continues posteriorly when performing the Le Fort I osteotomy. The risk of damaging the MA and its branches will be minimized with this maneuver.

\section{Discussion}

Despite its surgical importance, anatomic reports of the pterygopalatine portion of the MA are scarce, because of the difficulty in approaching this region. (-Fig. 4) To the best of our knowledge, this issue has been addressed by Montgomery et al., Potter, Pearson et al., and Wentges. ${ }^{11-14}$ Turvey and Fonseca ${ }^{15}$ described the relationship between the course of the MA in the PPF and the pterygomaxillary suture, a particularly useful finding in oral and maxillofacial surgery. Li et al. ${ }^{16}$ also described the localization of the descending

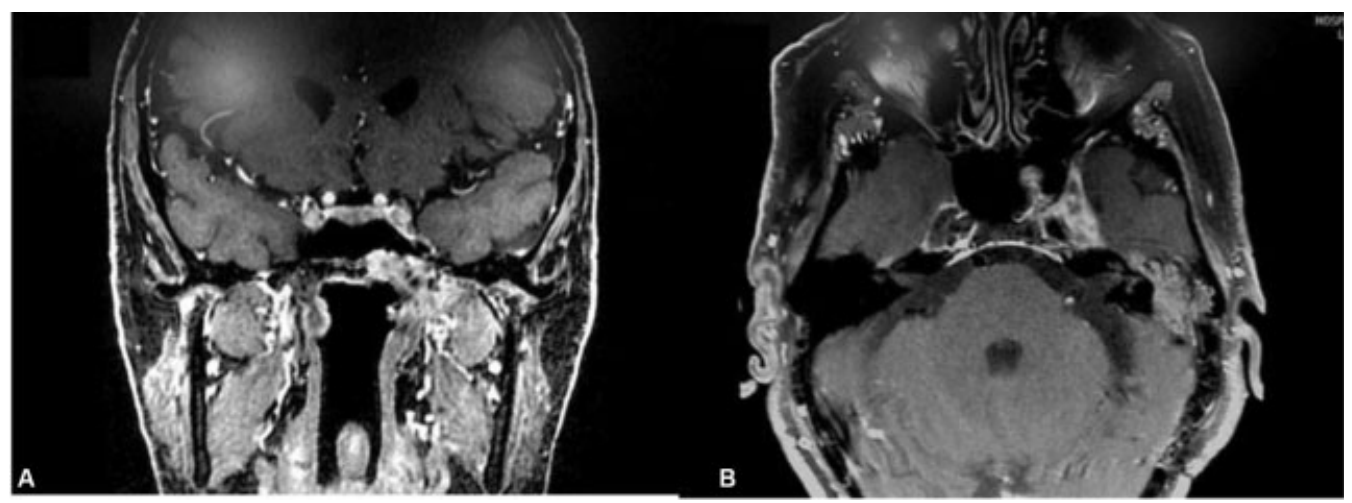

Fig. 4 Clinical example. Computed tomography scan. Endoscopic endonasal biopsy of the tumor in the pterygopalatine fossa reveled squamous cell carcinoma. Treatment was supplemented with radiation therapy. 
palatine artery concerning the Le Fort I osteotomy. To separate the pterygomaxillary junction, detailed knowledge of the PPF anatomy is crucial to surgeons. Understanding the course and variations of the MA and its branches in the PPF will help the surgeon prevent injury to this artery when performing midfacial osteotomies. - Fig. 4 illustrates a pterygopalatine fossa tumor-the biopsy revealed squamous cell carcinoma.

\section{Clinical Applications}

In the setting of a PPF mass lesion, the differential diagnosis includes perineural tumoral extension along the maxillary nerve, schwannomas or neurofibromas arising from this nerve, angiofibromas, hemangiomas, and-on rare instances -ectopic salivary gland tissue. In the investigation of these lesions, computed tomography (CT) provides information regarding the adjacent osseous structures, while magnetic resonance imaging (MRI) helps to characterize the lesion.

The finding of a lesion in the PPF has serious implications, both in treatment and prognosis. ${ }^{17,18}$ In the absence of a local destructive neoplasm, it often signifies the presence of perineural spread. The 5-year survival rate of patients presenting with sinonasal malignancies and invasion of the PPF is very low. ${ }^{19,20}$ Frequently, perineural spread into the PPF is also an indicator of increased tumor recurrence and reduced survival. ${ }^{17}$

On MRI, the normal PPF appears as a small fatty cleft between the posterior wall of the maxillary sinus, anteriorly, and the pterygoid plates, posteriorly. The fossa is best viewed on T1-weighted images because its contents are surrounded by hyperintense fat. It is usually bilaterally symmetric, containing small flow voids arising from branches of the maxillary artery. The presence of small emissary veins may cause mild enhancement within the PPF after the administration of contrast. ${ }^{8,17,21}$

Angiofibromas and hemangiomas, being vascular tumors, will enhance intensely following contrast administration, and may show abundant flow voids. A nasopharyngeal carcinoma extending into the PPF will replace fat in this location and, if extensive, may erode and enlarge the osseous limits of the fossa. Schwannomas are circumscribed, enhancing tumors that, when large enough, may also erode the osseous margins of the PPF. ${ }^{22}$ Encephaloceles and heterotopic brain might have signal characteristics similar to brain tissue on T1, T2, and proton densityweighted MRI.

The various anatomic communications provided by the PPF in the midfacial region explain why the spread of tumors and infections from the head and neck to the cranial base is typical. Many tumors arising from the perineurium spread in all these regions. This explains why the PPF, despite its limited size, has such an importance in cranial base surgery.

Many different methods have been used to produce regional anesthesia of the maxillary branch of the trigeminal nerve. ${ }^{23}$ Inserting a needle into the greater palatine canal through the greater palatine foramen and then applying the local anesthetic into the superior part of the PPF will result in profound anesthesia in the distribution of the maxillary nerve. ${ }^{24}$ This technique is useful in both maxillofacial surgery and dental treatment, providing a low incidence of complications. $^{25-27}$

\section{Standard Surgical Approach}

The standard approach to the PPF usually requires transmaxillary techniques. However, these techniques are limited by facial scars, prolonged recovery time, and possible effects on facial skeletal growth.,3,28 Endoscopic approaches are becoming increasingly more popular but have limited utility in far lateral access, increased operative time, and increased difficulty in achieving hemostasis in highly vascular tumors. $2,3,29,30$

Patel et al. ${ }^{1}$ described a modified lateral rhinotomy with maxillectomy technique for the treatment of PPF neoplasms. This new approach provides excellent access to most anatomic extensions and is cosmetically superior to the previously described techniques. It allows to preserve the infraorbital nerve and a portion of the maxillary periosteum and facilitates complete resection of PPF lesions.

\section{Endoscopic Approaches}

Surgically approaching the PPF is technically tricky, both because of its depth and bony encasement. Traditional open approaches, such as the Caldwell-Luc and lateral rhinotomy, have been primarily replaced by transnasal endoscopic approaches, which are less invasive and greatly minimize the postoperative morbidity associated with older approaches.

Concerning PPF biopsies, the majority of the image-guided cases reported in the literature used a transnasal approach with a medial maxillary antrostomy to gain access to the posterior maxillary wall. ${ }^{31}$ The image-guided transoral approach, described by Bleier and Mirza, has been reported to allow wide surgical exposure without the need for endoscopic equipment, also minimizing the potential morbidity of a wide maxillary antrostomy, such as orbital and nasolacrimal duct injury.

Using the endoscopic endonasal route, the PPF can be exposed through its anteromedial surface. ${ }^{32-37}$ When using this technique to approach lesions that invade the PPF through the lateral recess of the sphenoid sinus (LRSS), it is more critical to gain wide access to the LRSS, located medially, than to enlarge the surgical field laterally to expose the surface of the PPF completely. The latter maneuver should only be performed during the procedure if the surgeon notices that the lesion expands laterally.

Alfieri et al, ${ }^{22}$ using an endoscopic endonasal approach to the pterygopalatine fossa in cadavers, found that the Vidian nerve is an important anatomic landmark. The foramen lacerum was located posteromedially to it, the mandibular nerve was located posterolaterally, the Eustachian tube was located inferomedially, and the PPF was located anteriorly. In all the specimens studied, the pterygopalatine ganglion was found to be of triangular shape, reflecting the disposition of its three main branches: the Vidian nerve superomedially, the branch from the maxillary nerve superolaterally, and the greater and lesser palatine nerves inferiorly. It was also noted 
that small branches from the pterygopalatine nerve innervated the nasal and pharyngeal mucosa.

In their study, Alfieri et al. ${ }^{22}$ used three different approaches to the PPF. In the middle meatal transpalatine approach, a medial exposure of the PPF can be achieved. The Vidian nerve is found superomedially and can be followed to identify the pterygopalatine ganglion. The middle meatal transantral approach allows a broader exposure and is particularly indicated to approach the lateral PPF. At this location, the infraorbital nerve is easily identified. When the sphenopalatine artery cannot be identified, this approach is a valid alternative. At last, the inferior turbinectomy transantral approach allows the most extensive exposure, so that the infratemporal fossa can be easily approached.

At present, the best available non-endoscopic approaches to the PPF are more invasive when compared with their endoscopic counterparts. ${ }^{38}$ The transmaxillary and transpalatal approaches require extensive resection of bony structures and are narrow in the deeper part of the approach. This creates a cone-shaped surgical field, impairing the surgical vision and maneuverability. Endoscopic surgery solves this problem, bringing the light source to the center of the surgical field. An endoscope also allows proper visualization of the surgical field, with the possibility of extreme close-ups and different view angles when using changeable endoscopes. ${ }^{39-41}$

\section{Conclusions}

The pterygopalatine fossa is a cone-shaped space that contains multiple key neurovascular structures and its access, either endoscopic or microsurgical, can be challenging. We provide detailed information on the fossa's boundaries, intercommunications with adjacent structures, anatomy of the maxillary artery, and its variations. This anatomical knowledge is discussed in the context of clinical affections and surgical approaches of this specific region, including pterygomaxillary disjunction and skull base tumors.

\section{Conflict of Interests}

The authors have no relevant conflict of interests to declare.

\section{References}

1 Patel NJ, Ettema SL, Kerschner JE. Maxillary osteoplastic flap technique for the treatment of pediatric pterygopalatine fossa neoplasms. Int J Pediatr Otorhinolaryngol 2006;70(02):295-301. Doi: 10.1016/j.ijporl.2005.06.024

2 Scholtz AW, Appenroth E, Kammen-Jolly K, Scholtz LU, Thumfart WF. Juvenile nasopharyngeal angiofibroma: management and therapy. Laryngoscope 2001;111(4 Pt 1):681-687. Doi: 10.1097/00005537200104000-00022

3 Mann WJ, Jecker P, Amedee RG. Juvenile angiofibromas: changing surgical concept over the last 20 years. Laryngoscope 2004;114 (02):291-293. Doi: 10.1097/00005537-200402000-00020

4 Choi J, Park H-S. The clinical anatomy of the maxillary artery in the pterygopalatine fossa. J Oral Maxillofac Surg 2003;61(01):72-78. Doi: $10.1053 /$ joms.2003.50012
5 Kim HS, Kim DI, Chung IH. High-resolution CT of the pterygopalatine fossa and its communications. Neuroradiology 1996;38 (Suppl 1):S120-S126. Doi: 10.1007/BF02278138

6 Pandolfo I, Gaeta M, Blandino A, Longo M. The radiology of the pterygoid canal: normal and pathologic findings. AJNR Am J Neuroradiol 1987;8(03):479-483

7 Meloni F, Mini R, Rovasio S, Stomeo F, Teatini GP. Anatomic variations of surgical importance in ethmoid labyrinth and sphenoid sinus. A study of radiological anatomy. Surg Radiol Anat 1992;14(01):65-70. Doi: 10.1007/BF01628046

8 Chong VFH, Fan Y-F. Pterygopalatine fossa and maxillary nerve infiltration in nasopharyngeal carcinoma. Head Neck 1997;19 (02):121-125. Doi: 10.1002/(SICI)1097-0347(199703)19:2<121: AID-HED6>3.0.CO;2-6

9 Mazziotti S, Gaeta M, Blandino A, Vinci S, Pandolfo I. Perineural spread in a case of sinonasal sarcoidosis: case report. AJNR Am J Neuroradiol 2001;22(06):1207-1208

10 Lawson W, Reino AJ. Isolated sphenoid sinus disease: an analysis of 132 cases. Laryngoscope 1997;107(12 Pt 1):1590-1595. Doi: 10.1097/00005537-199712000-00003

11 Montgomery WW, Katz R, Gamble JF. Anatomy and surgery of the pterygomaxillary fossa. Ann Otol Rhinol Laryngol 1970;79(03): 606-618. Doi: 10.1177/000348947007900326

12 Potter GD. The pterygopalatine fossa and canal. Am J Roentgenol Radium Ther Nucl Med 1969;107(03):520-525. Doi: 10.2214/ ajr.107.3.520

13 Pearson BW, MacKenzie RG, Goodman WS. The anatomical basis of transantral ligation of the maxillary artery in severe epistaxis. Laryngoscope 1969;79(05):969-984. Doi: 10.1288/00005537196905000-00014

14 Wentges RT. Surgical anatomy of the pterygopalatine fossa. J Laryngol Otol 1975;89(01):35-45. Doi: 10.1017/ S0022215100080051

15 Turvey TA, Fonseca RJ. The anatomy of the internal maxillary artery in the pterygopalatine fossa: its relationship to maxillary surgery. J Oral Surg 1980;38(02):92-95http://www.ncbi.nlm.nih. gov/pubmed/6928026

16 Li KK, Meara JG, Alexander A Jr. Location of the descending palatine artery in relation to the Le Fort I osteotomy. J Oral Maxillofac Surg 1996;54(07):822-825, discussion 826-827. Doi: 10.1016/S0278-2391(96)90528-5

17 Ginsberg LE. Imaging of perineural tumor spread in head and neck cancer. Semin Ultrasound CT MR 1999;20(03):175-186. Doi: 10.1016/S0887-2171(99)90018-5

18 Curtin HD, Williams R, Johnson J. CT of perineural tumor extension: pterygopalatine fossa. AJR Am J Roentgenol 1985;144(01): 163-169. Doi: 10.2214/ajr.144.1.163

19 Goepfert H, Dichtel WJ, Medina JE, Lindberg RD, Luna MD. Perineural invasion in squamous cell skin carcinoma of the head and neck. Am J Surg 1984;148(04):542-547. Doi: 10.1016/0002-9610(84)90385-4

20 Gullane PJ, Conley J. Carcinoma of the maxillary sinus. A correlation of the clinical course with orbital involvement, pterygoid erosion or pterygopalatine invasion and cervical metastases. J Otolaryngol 1983;12(03):141-145http://www.ncbi.nlm.nih. gov/pubmed/6308278

21 Chong VF, Fan YF, Khoo JB, Lim TA. Comparing computed tomographic and magnetic resonance imaging visualisation of the pterygopalatine fossa in nasopharyngeal carcinoma. Ann Acad Med Singapore 1995;24(03):436-441http://www.ncbi.nlm.nih. gov/pubmed/7574428

22 Alfieri A, Jho H-D, Schettino R, Tschabitscher M. Endoscopic endonasal approach to the pterygopalatine fossa: anatomic study. Neurosurgery 2003;52(02):374-378, discussion 378-380. Doi: 10.1227/01.NEU.0000044562.73763.00

23 Poore TE, Carney MT. Maxillary nerve block: a useful technique. J Oral Surg 1973;31(10):749-755http://www.ncbi.nlm.nih.gov/ pubmed/4516663 
24 Loetscher CA, Melton DC, Walton RE. Injection regimen for anesthesia of the maxillary first molar. J Am Dent Assoc 1988; 117(02):337-340. Doi: 10.1016/S0002-8177(88)72020-6

25 Sved AM, Wong JD, Donkor P, et al. Complications associated with maxillary nerve block anaesthesia via the greater palatine canal. Aust Dent J 1992;37(05):340-345. Doi: 10.1111/j.18347819.1992.tb00758.x

26 Sweet WH. Trigeminal injection with radiographic control: technic and results. J Am Med Assoc 1950;142(06):392-396, illust. Doi: $10.1001 /$ jama.1950.02910240010003

27 Nish IA, Pynn BR, Holmes HI, Young ER. Maxillary nerve block: a case report and review of the intraoral technique. J Can Dent Assoc 1995; 61(04):305-310http://www.ncbi.nlm.nih.gov/pubmed/7736334

28 Tewfik TL, Tan AK, al Noury K, et al. Juvenile nasopharyngeal angiofibroma. J Otolaryngol 1999;28(03):145-151http://www. ncbi.nlm.nih.gov/pubmed/10410346

29 Roger G, Tran Ba Huy P, Froehlich P, et al. Exclusively endoscopic removal of juvenile nasopharyngeal angiofibroma: trends and limits. Arch Otolaryngol Head Neck Surg 2002;128(08):928-935. Doi: 10.1001/archotol.128.8.928

30 Nicolai P, Berlucchi M, Tomenzoli D, et al. Endoscopic surgery for juvenile angiofibroma: when and how. Laryngoscope 2003;113 (05):775-782. Doi: 10.1097/00005537-200305000-00003

31 Aronsohn MS, Stringer SP, Brown HM. Utility of image guided surgery in the diagnosis of pterygopalatine fossa lesions. Laryngoscope 2004;114(03):424-427. Doi: 10.1097/00005537-20040300000007

32 Alfieri A, Jho H-D. Endoscopic endonasal approaches to the cavernous sinus: surgical approaches. Neurosurgery 2001;49(02):354-360, discussion 360-362. Doi: 10.1097/00006123-200108000-00017

33 Al-Nashar IS, Carrau RL, Herrera A, Snyderman CH. Endoscopic transnasal transpterygopalatine fossa approach to the lateral recess of the sphenoid sinus. Laryngoscope 2004;114(03): 528-532. Doi: 10.1097/00005537-200403000-00026

34 Başak S, Karaman CZ, Akdilli A, Mutlu C, Odabaşi O, Erpek G. Evaluation of some important anatomical variations and dangerous areas of the paranasal sinuses by CT for safer endonasal surgery. Rhinology 1998;36(04):162-167http://www.ncbi.nlm. nih.gov/pubmed/9923058

35 Cheung DK, Attia EL, Kirkpatrick DA, Marcarian B, Wright B. An anatomic and CT scan study of the lateral wall of the sphenoid sinus as related to the transnasal transethmoid endoscopic approach. J Otolaryngol 1993;22(02):63-68http://www.ncbi.nlm. nih.gov/pubmed/8515518

36 Mutlu C, Unlu HH, Goktan C, Tarhan S, Egrilmez M. Radiologic anatomy of the sphenoid sinus for intranasal surgery. Rhinology 2001;39(03):128-132http://www.ncbi.nlm.nih.gov/pubmed/ 11721501

37 Sethi DS, Stanley RE, Pillay PK. Endoscopic anatomy of the sphenoid sinus and sella turcica. J Laryngol Otol 1995;109(10): 951-955. Doi: 10.1017/S0022215100131743

38 Pasquini E, Sciarretta V, Farneti G, Ippolito A, Mazzatenta D, Frank G. Endoscopic endonasal approach for the treatment of benign schwannoma of the sinonasal tract and pterygopalatine fossa. Am J Rhinol 2002;16(02):113-118

39 Cappabianca P, Cavallo LM, de Divitiis E. Endoscopic endonasal transsphenoidal surgery. Neurosurgery 2004;55(04):933-940, discussion 940-941. Doi: 10.1227/01.NEU.0000137330.02549.0D

40 Cappabianca P, de Divitiis E. Endoscopy and transsphenoidal surgery. Neurosurgery 2004;54(05):1043-1048, 1048-1050. Doi: 10.1227/01.NEU.0000119325.14116.9C

41 Elwany S, Elsaeid I, Thabet H. Endoscopic anatomy of the sphenoid sinus. J Laryngol Otol 1999;113(02):122-126. Doi: 10.1017/ S0022215100143361 